1. THE SOCIAL MEDIA LANDSCAPE 2

1.1 A Treasure Trove OF DATA

2. IMPORTANCE OF SOCIAL MEDIA MEASUREMENT AND MONITORING 4

3. THE SOCIAL MEDIA MEASUREMENT AND MONITORING (SMM) PROCESS

3.1 SOCIAL MEDIA AUDIT

3.2 MAP OBJECTIVES

3.3 BUILD KPIS

3.3.1 PERFORMANCE METRICS

3.3.2 BUILDING KPIS

3.4 QUANTIFY TARGETS

3.5 STANDARDIZE MEASURES

3.6 COMPARATIVE ANALYSIS

18

FROM PERFORMANCE METRIC TO CALCULATION: TABULATION OF VARIOUS

PERFORMANCE METRICS WITH KPI AND CALCULATIONS 21

3.7 RECALIBRATE

5. DATA VISUALIZATION 
"One person's data is another person's noise."

- K.C. Cole (Author of the Universe and the Teacup)

\section{THE SOCIAL MEDIA LANDSCAPE}

The importance of social media has been increasing exponentially and has warranted many discussions about the importance of social media marketing and apportioning marketing budgets for social media. A recently conducted survey of about 3000 marketers by Salesforce to discuss State of Marketing in 2015 and in the future, (Salesforce.com, 2015) revealed that 66\% of marketers have a dedicated social media team, and $64 \%$ feel that it is a critical enabler for their business. Social Media is also considered an element of the promotional mix and an important integrated marketing communication (IMC) tool (Mangold and Faulds, 2009). It has also been pegged as one of the key areas where spending is expected to increase in the coming years. However, none of these discussions can come to fruition unless the right approach and tools are considered to monitor and measure the developments in social media marketing.

Organizations are engaging in a whole gamut of activities when it comes to social media such as content generation, content publishing, content distribution, social media advertising, and social media customer service. Besides, they are also defining specific strategies for different social media channels such as Facebook, Instagram, Twitter, Snapchat and the like. With such an increasingly complex social media landscape, the pertinent question that all brands and social media managers are seeking to understand is, how can they keep track of where this effort is headed? Measuring the effectiveness of these efforts is essential to calibrating future efforts, 
and even for apportioning funds accordingly. One of the recommendations that came forward from the report on State of Marketing (Salesforce.com, 2015) was that organizations should engage in social listening to make sure that they are covering all bases when it comes to monitoring their brands or topics relevant to their brands. If someone is talking about the brand somewhere, the organization should know.

\subsection{A Treasure Trove of Data}

Social Media sites such as Twitter, Facebook, Instagram, Pinterest, LinkedIn and Snapchat are a treasure trove of data. Consumers constantly engage with brands, as do film and television celebrities, politicians, sportspersons, musicians, company employees and even your neighbor with a peculiar sense of humor.

But before proceeding further, we need to establish the scope of customer engagement particularly in the context of social and digital marketing. The term “customer engagement" has gained widespread practitioner and academic attention particularly with the transition to more social channels. Traditionally customer engagement has been proven to enhance sales (Neff, 2007), competitive advantage (Sedley, 2006) and innovation (Sawhney, Verona and Prandelli, 2005). But what exactly is customer engagement?

Hollebeek, 2011 defines customer brand engagement as follows:

"The level of an individual customer's motivational, brand-related \& contextdependent state of mind characterized by specific levels of cognitive, emotional \& behavioral activity in brand interaction" 
The following caveats can be noted about engagement

- Engagement is characterized by a two way interaction between consumer and a product/brand (Bowden, 2009)

- Engagement yields in "customer repeat patronage, retention and loyalty" (Verhoef, Reinartz and Krafft, 2010)

- "Online customer engagement" is characterized by "active sustained cognitive processing", "instrumental value" and "experiential value" (Mollen and Wilson, 2010)

Organizations and brands need to monitor and measure the voice of the customer across various structured and unstructured messages, key words, hashtags, communities and be well equipped to address complains with the resources necessary to respond to crisis situations. That sounds like a lot of work for social media managers, however in order to plan better, most organizations have guidelines to make the process smooth.

The objective of this chapter is to highlight the role that social media measurement and monitoring processes can play in influencing business outcomes based on consumer behavior analysis.

\section{IMPORTANCE OF SOCIAL MEDIA MEASUREMENT AND MONITORING}


Consumers today have more devices and control at their fingertips, and are not afraid to explore and use various technologies available to them. And with the presentation of new connected and wearable devices and communication channels, it has become even more important to continuously monitor the consumer behavior across relevant channel touchpoints in order to serve the consumer better with relevant offerings at the right time. In the era of Snapchat and Facebook, which largely started out as millennial fads, why is it important to talk about Social Measurement and Measurement (SMM)? The answer to this question lies in understanding how monitoring and measurement of social media helps organizations. Below we illustrate the benefits of the 4 E's of the SMM process.

1. Engage Consumers: Consumers talk about brands on social media using myriads of hashtags, keywords, geolocation details, tags and content types such as photos, videos etc. In order to understand what is being said, organizations must actively listen and monitor online conversations about the organization itself or a particular brand, product category or campaign. Successful SMM processes yield actions that not only engage consumers but also enable organizations to drive towards consumer-first strategies.

2. Enhances Focus: SMM processes help organizations to maintain an enhanced focus on its marketing strategy and operations objectives within the social media sphere. By spelling out the important business objectives and how it can be measured, recalibrates the focus of the organization on the issues that are important. 
3. Educates Performance: Successful SMM processes enable organizations to continuously learn how to perform better vis a vis competitors. It also facilitates the reporting of relevant findings to any stakeholders within the organization.

4. Enables Return on Investment (ROI) Discussion: SMM process enables the linking of returns to the cost incurred on social media marketing efforts either at a strategic and organizational level or at the marketing campaign and operational level. This enables organizations decide if and how investment should be made across the social media value chain.

\section{THE SOCIAL MEDIA MEASUREMENT AND MONITORING (SMM) PROCESS}

The social media measurement and monitoring process is carried out to measure and monitor social media activities so organizations can achieve its goals.

First, the process begins with a social media audit to assess how efficiently and effectively the brands' existing social media efforts are performing, as well as evaluating where the consumers are engaging and communicating.

Second, mapping of objectives is carried out to understand direction of brand in regards to its efforts on social media and what it aims to achieve. Based on the different objectives various organizations may have, different strategies may have to be adopted. For instance, objective mapping could include deciding whether the goal of the brand is to seek feedback from consumers, provide customer service or increase brand awareness. 
Third, brands would need to draw out key performance indicators (KPIs) for each objective, and that would be the foundation in determining what is to be measured. An example of a KPI is Fan Growth rate (see Table 7) which tracks the growth of fans on a social media channel over a period of time.

Fourth, brands would have to set out quantifiable targets, and depending on the objective and the KPI these could range from a simple number of followers on Twitter to the number of comments on a post on Facebook. Further, brands could look to the market leader or its competitor to identify the target it wants to establish.

Fifth, the company would choose various measurement tools and chalk out approaches to measure the indicators they have established. These tools range from sentiment analysis and content analysis to automated tools and software that enable measurement and analysis.

Sixth, would be to perform a comparative analysis - to see how the actual indicators stack up against the targets, and then finally, recalibrate the social media strategy accordingly. Figure 1 gives a representation of the process.

The next sections discuss each of these steps in greater detail.

\section{INSERT FIGURE 1 NEAR HERE}

\subsection{Social Media Audit}

Social Media Audit involves performing a reconnaissance of the brands social media landscape. Brands may already be engaged in various social media activities 
such as a brand page on Facebook, Instagram account and a Twitter handle. Before the SMM process is to commence it is essential to understand the brands exposure in terms of the platforms that they are active on and how those initiatives are working for them. However, a mere presence on a platform is not the only parameter that needs assessment. It is also essential to understand what type of engagement is carried out on each platform, how regularly is the platform monitored, and whether the brand's consumers regularly engage in the platform under consideration. The level of engagement can be varied across platforms - for instance on Twitter the brand may just be retweeting praises sent to it by consumers, but on Facebook a brand could be posting original content such as pictures from events and contests. A social media audit should be able to capture the status quo of social media activities being performed by the brand across platforms and also gauge the effectiveness across each platform. Table 1 provides a social media audit template.

\section{INSERT TABLE 1 NEAR HERE}

While the template provided is just an example of how a social media audit can be performed, the template can also be amended to include other fields - for instance most popular content posted (with the most likes), the format of the most popular content (video, audio or image). Also, the frequency tab could be used to record the frequency with which the brand posts content rather monitors content. 


\section{Brands on Twitter}

The most followed brand on Twitter is Chanel. Surprised? It has 12.2 million followers. This is followed by Samsung Mobile with 11.9 million followers and Starbucks with 11.7 million followers (Socialbakers, 2016). However, Samsung ruled the roost only 6 months before. Chanel mostly tweets original content usually pictures and does not retweet any content. There are negligible to no conversations with followers. Moreover, there is evidence to show that Chanel posts at least one piece of content every day, sometimes more. What may have catapulted Chanel from the third spot six months ago to the top spot as far as Twitter followers go, ahead of Samsung Mobile?

Can you perform a social media audit for your favorite brand using the template provided? What do you think are the strengths and weaknesses of the brands social media strategy?

\subsection{Map Objectives}

After the social media audit is performed, the next step would be to enter the SMM process loop. The loop starts with mapping of objectives. In terms of social media, there can be several objectives for brands that may need attention. At a time they may want to address one or many objectives, however that remains the discretion of the organization based on its overall marketing strategy, the social media audit performed and any developments in the market.

Mapping Objectives for Social Media can be driven by: 
1. Need to learn from consumers: Brands thrive on knowing their consumers and offering products and services they want. In order to do that brands can seek feedback and ideas from consumers to fine tune their value propositions. This would also enable them to reduce cost, increase revenues, and amplify their reach and engagement.

2. Potential expansion into new markets: When brands want to acquire new markets they may have to develop objectives that enable it to increase its reach and acquire new customer. A tactical objective to increase reach would be to increase brand awareness.

3. Push to increase sales: Brands must grow and this is governed by more and more consumers buying their products and services. If the need is to increase sales, brands may decide to formulate a social media objective of creating engagement with its e-commerce platform.

4. Enhance customer satisfaction and increase loyalty: Cost of acquisition of a new customer is higher than simply retaining an existing customer. Thereby, if brands can keep their customers satisfied and happy they are bound to be loyal (Heskett et al., 2008). From a strategic view point, the brand should aim to increase engagement with consumers. Providing mechanisms for customer service and complaint redressal could be an objective that helps in this direction

5. Brand Equity: Social Media engagement can increase brand equity (Kim and Ko, 2012). Brands should create engaging content to improve brand equity. 
Depending on the business driver, sample tactical objectives can be drafted. For example, an airline may want to enhance customer satisfaction through engagement. To achieve this, they may want to reduce hold times on telephones and provide greater customer service. They may have alternate options for consumers to reach them such as via Twitter, Facebook or E-mail, but if people don't see how the airline engages on these platforms and what their response rates and times are, they may not be prompted to use these mediums and prefer to call instead. Thus bringing traffic from call centers to social media could be a big challenge for a brand. If done right, it can help keep costs down and enhance customer satisfaction. Promoting enhanced responsiveness on social channels, could be one way airlines could get more people to get customer service through Twitter or Facebook. At the time of this writing KLM, Royal Dutch Airlines (@KLM), has announced on its twitter profile page that it's average response time is 88 minutes and this is updated every 5 minutes.

What is the KLM average response time now as mentioned on its Twitter profile now? How does this compare with other airlines' response time?

National Geographic (@ natgeo) is the most followed brand on Instagram. It has more than 50 million followers (Instagram, 2016). National Geographic posts more than one stunning photo and sometimes several photos a day. However, one must be cognizant of the fact that the people are engaging with the content by commenting, liking or sharing it. For a brand like National Geographic it would be important to understand engagement, which may be a more relevant objective than brand awareness. As the National Geographic Instagram account already has a huge 
following, the real test would lie in knowing how people are engaging with the content posted by National Geographic over how many new followers it acquired over a period of time.

\subsection{Build KPIs}

The pace at which communication has shifted from traditional closed communication medium, such as call center services and email conversations, to a much publicly visible and highly reactive medium, such as the social media conversations has positioned social media community as one of the key critical community in brand success. As a social media community manager, it has become even more important to regularly monitor the existing and evolving social media networks to understand the customers, listen in to the trends, review campaign performance and track competitors. And with so much information available online, as well as offline, it is often difficult to make sense of the statistics and indicators across all channels. In many cases, having clear performance metrics, goals, and KPIs will help brands determine how to effectively and efficiently react to a given situation.

\subsubsection{Performance Metrics}

We will broadly classify the performance metrics into three groups, namely,

- Reach to increase awareness,

- Influence \& Engagement to generate leads \& nurture relations, and,

- Raise Revenues to focus on sales growth

\section{Reach}


Reach helps focus on the probable size of user base, based on the number of unique impressions, followers, shares, comments, and likes. Brands can execute campaigns that can enable them to reach their target audiences in three way - via organic reach, paid reach and viral reach.

- Organic Reach: Anything unpaid or that which grows naturally is organic. For example, users viewing or engaging with content or messages which are distributed by the brands naturally and without any paid sponsorship. Let's say, Andy and Anne are active users of Twitter and Facebook respectively. Andy's twitter feed and Anne's Facebook wall shows a video content posted by the brand. Whether Andy and Anne engage with this video content or not, if the content appears in their respective channel feeds, then the brand's organic reach went up by 2 . Brands can further filter this number by gender, channel, geographies etc. to accurately measure the organic reach.

- Paid Reach: Any sponsorship or payment involved in promoting content or messages is paid reach. For example, users viewing or engaging with content or messages which are distributed by brands via paid networks. Let's say, if brand A buys a sponsored tweet in Twitter or a sponsored post in Facebook, then the tweet or the post appears in the users feed. The paid networks allow brands to specify their target demography, region, gender etc., which facilitates targeted marketing.

- Viral Reach: Viral reach is achieved when posts are visible in a user's feed from the people, brand, ambassadors or celebrities that the user may have followed/liked, commented on or re-shared. Let's say, Andy is friends with 
Anne. Andy likes the campaign status message of brand A which is publicly visible on Facebook. This status is then also visible to Anne, which Anne may likely to comment, re-share or like. This comprises viral reach.

\section{Influence and Engagement}

While reach helps gauge the opportunity size, influence and engagement measure the exposure potential of campaign content or messages. The influence and engagement performance metric is important to measure the amplification potential of a campaign content and the corresponding behavior of the brands' audiences towards the campaign over time. This in turn helps brands to measure the customer acquisition and/or sales conversion potential.

Figure 2 below depicts the degree of separation between the brand and its audiences i.e. fans/followers, and the influence that a brand can capitalize on. A brand on a social media channel must actively listen and continuously engage with its audience to evaluate what is echoing with its immediate fans/followers, and their engagement and influencing potential to reach wider audiences. Such degrees of influences and engagement are likely to provide with formidable insights that will further help finetune the content creativity and creation, as well as the overall campaign messaging.

\section{INSERT FIGURE 2 NEAR HERE}

\section{Raising Revenues}

Revenue focused metrics are critical and justify the effort, budget and resources put towards the social media marketing program. But it is commonly believed that the 
complexities involved in measuring social media revenue metrics makes the measurement criteria a challenge, especially when the campaign initiatives are spread across multiple social media channels and touch points. No KPI is complete without appraising the revenue objectives, and brands can overcome the challenges and complexities as long as the metrics and KPIs are clearly tied to the overall business goals, clearly articulated and aligned with relevant stakeholders.

When building KPIs to measure the reach of a brand, the following questions must be asked:

Q1: What social media channels is the brand using for its campaigns?

Q2: How are consumers/customers reaching the brand?

\subsubsection{Building KPIs}

Setting clear KPIs will enable brands to report the progress and performance of one or more campaigns across a number of social networks to senior management, and help evaluate the areas to engage, improve, invest or even withdraw.

\section{INSERT TABLE 3 NEAR HERE}

For example, consider the fan growth rate KPI. Fan growth rate allows brands to track fans/followers growing over time. Fan growth rate is useful when appraising how quickly the brand is growing. Such a KPI help estimate the influence potential the brand can capitalize on by reaching out to its fans/followers and possibly engaging with them. However, note that one must not just rely on one KPI to determine the success of a campaign, but instead must focus on all goal relevant and 
correlated KPIs. Quality of fan/follower or likely leads can be used in conjunction with fan growth rate KPI under consideration to build relevant and meaningful insights.

With a number of metrics offered by various social media networks, it is often difficult to determine which KPIs are relevant and align with the business objectives. When developing KPIs, understanding and evaluating what is relevant for the brand is essential. For example, asking questions such as the follows will help outline clear KPIs:

- What are the objectives to be achieved from social media marketing?

- What social media channels to consider for campaign management?

- How are the consumers reaching the brand?

- Which KPIs are in use and how efficiently will it measure success?

- Are KPIs to be evaluated in silos or correlated with other KPIs?

INSERT TABLE 4 NEAR HERE

\subsection{Quantify Targets}

Once the KPIs are defined, they must be linked to the strategic business metrics and goals. KPIs must be measurable in order to benchmark the growth objectives to deliver; and concrete in order to assess the necessary budget and resources required to execute the operations.

\section{INSERT FIGURE 3 NEAR HERE}


For example, if a brand is looking to increase number of followers (fan growth rate) across a breadth of social media platforms such as Twitter, Facebook, Instagram and Snapchat, but fails to do so on a given platform, say Twitter, then the campaign is not completely lost. The brand needs to now measure the overall percentage increase in the number of fans/followers across various social media channels, including Twitter as a first. It can also focus instead on measuring the increase in audience, who may have seen the brands content organically, or via sponsored posts, even though they may not be fans or followers of the brand. .

Such a measurement provides great insight in evaluating the investments in tools, resources and social media channels necessary for future campaigns. However, it should be noted that fan growth rate is not an accurate indication of the quality of the fan/follower base. A better tool for assessing the quality of the fan/followers could be sales leads (See Table 11) or monitoring network influencers. For instance Kylie Jenner who has 76.2 million followers (as in October 2016) on Instagram is considered an influencer in the domain of beauty and fashion. A leading fashion brand may find that a mention of their product or brand by a notable network influencer like Kylie Jenner can help their reach increase exponentially.

Quantifying social media objectives is always challenging, and hence when developing targets, determining the practical and measurable goals relevant to the brand is critical. For example, asking questions such as the follows will help outline clear measurable KPIs,

- What should the business aim to achieve with the KPI?

- What measures are the competitors within the industry adopting? 
- What budget, resources, and technology are available to meet this target?

- Is the target realistic and does it take into account all factors to reach the goal?

- Does the target have milestones or deadlines and is it measured regularly?

For example; If the brand has decided to focus on the performance metric of Reach, in order to enhance brand awareness and drafted a KPI of fan growth rate, how does it decide what would constitute a reasonable fan growth rate percentage? Some approaches of quantifying targets include:

- Market leader: A brand could decide to fix a target based on the fan growth rate of the market leader on a select social media channel.

- Competitor: A brand could also fix its target based on the fan growth rate of its closest competitor.

- Event Driven Decision: A potential development in the business environment could also guide the target quantification. For example, if a brand is sponsoring an event, then during the airing of the event it may quantify its target for fan growth rate higher than usual due to the increased visibility during that period.

\subsection{Standardize Measures}

The 'I' in the KPI refers to the indicator, which is nothing but statistics and arithmetic values associated with an activity. The arithmetic values give a scorecard about the performance of the activity at given point in time or over a certain period, and helps benchmark the performance against an indicator. 
While indicators are usually easy to quantify and calculate, brands may still need to create custom scale of measurements, and also decide upon the best computation methods to report such as, percentages, counts, totals, averages or ratios.

\section{INSERT TABLE 5 NEAR HERE}

For example, if the brand is measuring the fan growth rate for a specific channel say Instagram over a quarter, then then it can either measure the percentage increase or decrease in the number of fans between the start of the quarter and the end of the quarter. However, if a brand wants to measure the quality increase or decrease in the number of fans, then many factors could potentially be introduced into the calculation such as number of authorized Instagram accounts, audiences acquired through loyal fans/followers, leads to sales conversions etc.

Quantifying social media objectives is always challenging, and hence when developing KPIs, it is good practice to determine the practical and measurable goals relevant to the brand. For example, asking questions such as the follows will help outline clear measurable KPIs,

- Is the KPI objective well understood?

- Can the KPI be easily measured?

- Are all the factors and assumptions considered to compute the KPI?

- Is the KPI simple and easy to explain?

- Does the measurement depend on other KPIs? 


\subsection{Comparative Analysis}

Comparative analysis is about comparing apples to apples of two or more alternatives such as campaigns, content, content type, message, brand ambassador, sub-brands or the likes. In social media terms, for example, say, the change in fan growth rate may be presented over a period of time and benchmarked against one or more competitors to evaluate the overall standing of the brand reach with respect to the social media or company goals. Comparative analysis fully estimates the completeness of measuring the success of the KPI as well as the brand within (sub brands, if any) and outside (competitors) of the brand ecosystem.

\section{INSERT TABLE 6 NEAR HERE}

In the example highlighted in Table 6, for the month of January, Company A has grown positively, lagging in the race with Company B, but leading in the race with Company C.

Performing a comparative analysis over time, across regions, demographics, social media channels, as well as benchmarking against family of brands, competitors or campaigns will enable brands to effectively and efficiently compute and measure the success of the initiative.

The level of details to engineer comparative analysis must be based on the resources available and importance of the KPI. For example, asking questions such as the follows will help outline clear comparative analysis for a given KPI,

- Why does the brand need comparative analysis? 
- Are there enough parallels to perform meaningful analysis?

- Is the limitation to analyze, compare various data points understood?

- How frequently must the comparative analysis be executed?

- What is the level of detail to evaluate the comparison on?

From Performance Metric to Calculation: Tabulation of various Performance Metrics with KPI and Calculations

INSERT TABLE 7 NEAR HERE

INSERT TABLE 8 NEAR HERE

INSERT TABLE 9 NEAR HERE

INSERT TABLE 10 NEAR HERE

INSERT TABLE 11 NEAR HERE

\subsection{Recalibrate}

Based on the findings during measurement and comparative analysis stage a brand may decide to recalibrate its approach. The need for recalibration could arise due to:

- Non-achievement of the targets: If a brand is unable to achieve its target it would need to investigate the reason for falling short. Was the non achievement due to the target being set at an overzealous level or did they fall short in their efforts?

- Changes in the environment: A change in the external environment or internal environment of the brand can also force a recalibration of the SMM process. If the brand expects a cut in the social media marketing budget, it may have to forego certain resources and dial down its targets. 
- Misguided KPI: A brand may have erroneously decided to focus on a KPI, which may not have been relevant to the business. For instance, a brand looking to increase brand awareness and increase brand engagement may have decided to focus on sales from social media leads rather than applause rate average (See Table 9). While the first KPI is linked to revenue, the second is more about influence and engagement. The brand may want to focus on the applause rate average to tap into influence and engagement.

\section{SENTIMENT VISUALIZATION}

With so much content being created and shared on social networks, brands need to constantly listen in to relevant conversations, words, and themes to be informed about sentiment around their products, brands and the organization itself. The listening has to be in accordance to privacy and security laws regulated in the region, and calibrated according to the goal. If the goal is awareness then one way of measuring it would be to see how many people are using the name of the brand in conversations across social and to what extent is the conversation positive or negative. This is where sentiment analysis or opinion mining would fit in. Usually, considering the number of data points, sentiment analysis is performed by written programs. To perform it manually for 500 million tweets sent out every day would be humanly impossible. There is a range of tools available to track sentiment online.

The tweet sentiment visualization (Tweet Sentiment Visualization, 2016) developed by Healey and Ramaswamy at NCSU is one such free website. Type in a keyword and you are presented with a graph plotting the tweet text across a range of 
sentiments such as unpleasant to pleasant, active to subdued, (On the $\mathrm{X}$ and $\mathrm{Y}$ axis respectively) and among other sentiments as well such as depressed, excited, nervous, and calm. The graph can also show each data point used to craft the sentiment analysis, in this case clicking on each circle shows you the corresponding tweet. A keyword search for the hugely popular augmented reality game "Pokemon Go" developed by Niantic yields a vast amount of positive data points. (See Figure 4)

\section{INSERT FIGURE 4 NEAR HERE}

However, machine driven sentiment analysis can sometimes lead to misleading results, considering it is difficult for an algorithm to account for the cultural linguistic nuances, sarcasm and double entendre. This often leads to confusion in classification. For a tweet that says "This cupcake is wickedly sinful" to be perceived as negative by the algorithm would be very wrong and give a wrong indication to the brand about the sentiment surrounding it. Alternately, for two statements with similar words but different meanings such as "I want the new iPhone SO bad" vs "the new iPhone is so bad", sentiment analysis coding would classify them in the same way - negatively, as the automated code cannot read between the lines in terms of the context.

Another example, a music production house tracking the sentiment for a new song, and it gets a sentiment bordering on the negative, could it be due to the presence of 
tweets such as "This song is sick!"? Perhaps it is something to think about before relying completely on algorithm driven sentiment analysis.

There are some tools which organizations can use, but it really depends on the sophistication of the algorithm. Better yet they can get experts to perform a sentiment analysis on a small sample of text manually. 


\section{DATA VISUALIZATION}

Data visualization is the process of collecting the data and exhibiting the data in a graphical format, which allows complex information to be conveyed in easy to interpret format and story.

"A picture is worth a thousand words" - English idiom

\section{INSERT FIGURE 5 NEAR HERE}

The ever-evolving nature of social media means that there are new social media networks, technologies and interaction features emerging every year. More networks mean more customers engaging across various channels, and eventually more data to process and interpret. Brands can either choose to manually process the data and ingest the results within the brand ecosystem, or automate the data gathering and ingestion process. This can be achieved by using the public application program interface (API) exposed by various social media channels for easy to measure parameters.

\section{CONCLUSION: DON'T GET OBSESSED WITH NUMBERS}

Isn't social media measurement and monitoring enthusing? Brand may have multiple digital touchpoints and journeys which may involve solidifying brand awareness, generating leads, acquiring new customers, retaining existing customers and growing revenues. It is indeed possible that certain deadlines, targets, and goals may not be achieved. With plethora of data and insights, social media managers 
must be able to assess how to navigate from social media on through to recalibrating the KPIs in the SMM process (see Figure 1).

Regardless of the consumer journey mapped out, it is important that brands maintain a clear goal-driven approach, which is aligned with the overall business goals in order to evaluate the social media marketing efforts. At the end, it is important to be realistic, measure wisely! 


\section{References}

Bowden, J. L.-H. (2009) The process of customer engagement: A conceptual framework, Journal of Marketing Theory and Practice, 17(1), pp. 63-74.

Heskett, J. L., Jones, T. O., Loveman, G. W., W. Earl Sasser, J. and Schlesinger, L. A. (2008) Putting the Service-Profit Chain to Work, Harvard Business Review, [online] Available at: https://hbr.org/2008/07/putting-the-service-profit-chain-towork (Accessed 29 July 2016).

Hollebeek, L. D. (2011) Demystifying customer brand engagement: Exploring the loyalty nexus, Journal of marketing management, 27(7-8), pp. 785-807.

Instagram (2016) National Geographic (@natgeo) • Instagram photos and videos, [online] Available at: https://www.instagram.com/natgeo/ (Accessed 29 July 2016).

Kim, A. J. and Ko, E. (2012) Do social media marketing activities enhance customer equity? An empirical study of luxury fashion brand, Journal of Business Research, Fashion Marketing and Consumption of Luxury Brands, 65(10), pp. 1480-1486.

Mangold, W. G. and Faulds, D. J. (2009) Social media: The new hybrid element of the promotion mix, Business horizons, 52(4), pp. 357-365.

Mollen, A. and Wilson, H. (2010) Engagement, telepresence and interactivity in online consumer experience: Reconciling scholastic and managerial perspectives, Journal of business research, 63(9), pp. 919-925.

Neff, J. (2007) OMD proves the power of engagement, Advertising age, 78(27), pp. 3-4.

Salesforce (2015) The State of Marketing Report 2015. Available from:

https://www.salesforce.com/form/marketingcloud/2015-state-of-marketing.jsp

Sawhney, M., Verona, G. and Prandelli, E. (2005) Collaborating to create: The Internet as a platform for customer engagement in product innovation, Journal of interactive marketing, 19(4), pp. 4-17.

Sedley, R. (2006) 'Annual Online User/Customer Engagement Survey 2006, 28, p. 2011 (Accessed May 2016)

Tweet Sentiment Visualization (2016) Tweet Sentiment Visualization App, [online] Available at: https://www.csc.ncsu.edu/faculty/healey/tweet_viz/tweet_app/

(Accessed 30 July 2016).

Verhoef, P. C., Reinartz, W. J. and Krafft, M. (2010) Customer engagement as a new perspective in customer management, Journal of Service Research, 13(3), pp. $247-252$. 


\section{About the Authors}

\section{Mudra Mukesh}

Dr. Mudra Mukesh is lecturer in Digital Marketing at University of Greenwich, London. She has PhD in Marketing from IE Business School, IE University in Madrid, Spain. Mudra has studied and worked in India, France, China, Hong Kong and USA. She has researched how Facebook usage impacts well-being of individuals and consumption preferences as well as negotiation behavior. She is interested in understanding how cognitive and social psychology can address issues and solve problems in education and addiction. Some of her other research projects include but are not limited to: socio-economic determinants of harmful consumption, logo design, impact of time orientation on well-being and impact of envy on behavior and consumption.

Mudra's research has received widespread media coverage from Live Science, Men's Health and L'Express. It has also been presented at various global academic conferences.

\section{Anand Rao}

Anand Rao specializes in conceptualizing Omni channel digital transformation solutions with/for industry leading brands across industry sectors. Anand is wellversed with the online world, and has worked on large scale digital strategy \& operations initiatives with world renowned brands and promising startups - from apparels/accessories, diversified chemicals \& decorative, telecom and travel sectors to successful start-up experiences in Media and Finance sectors - to innovate, drive change and deliver sustainable business benefits. He is passionate about creating effective digital experiences and using data to inform creative and business decisions.

Anand is an MBA Graduate of IE Business School and alumnus of University of Mumbai. 
FIG 1: THE SOCIAL MEASUREMENT AND MONITORING PROCESS (SMM PROCESS) 31

TABLE 1: SOCIAL MEDIA AUDIT TEMPLATE

TABLE 2: SOCIAL MEDIA OBJECTIVES AND DRIVERS

FIGURE 2: INFLUENCE A BRAND CAN CAPITALIZE ON $\quad 34$

TABLE 3: ORGANIZING THE PERFORMANCE METRIC, PURPOSE AND KPIS 34

TABLE 4: EXERCISE TEMPLATE - DEFINING A KPI 35

FIGURE 3: EXAMPLE - DEVELOPING SOCIAL KPIS FROM METRICS TO TACTICS $\quad 36$

TABLE 5: VARIOUS COMPUTATIONS TO DETERMINE FAN/FOLLOWER GROWTH $\quad 36$

TABLE 6: COMPARATIVE ANALYSIS OF FAN GROWTH FOR IANUARY

TABLE 7: FAN GROWTH RATE $\quad 38$

TABLE 8: SENTIMENT INDICATOR

TABLE 9: SHARE OF CONVERSATIONS VS. COMPETITORS

\begin{tabular}{lr} 
TABLE 10: AMPLIFICATION RATE & 41 \\
\hline
\end{tabular}

TABLE 11: APPLAUSE RATE AVERAGE $\quad 42$

TABLE 12: SOCIAL MEDIA RETURN ON INVESTMENTS (ROI)

TABLE 13: SALES FROM SOCIAL MEDIA LEADS

FIGURE 4: TWEET SENTIMENT VISUALIZATION FOR KEY WORD “POKEMONGO” $\quad 45$

FIGURE 5: TWEET SENTIMENT VISUALIZATION FOR KEY WORD “POKEMONGO"

SHOWING A HIGH CONFIDENCE/PLEASANT AND ALERT/ACTIVE TWEET. 46

FIGURE 6: BAR CHART - NUMBER OF FANS/FOLLOWERS FOR DIFFERENT BRANDS AGAINST COMPETITOR FOR A GIVEN PERIOD 46 
Fig 1: The Social Measurement and Monitoring Process (SMM Process)

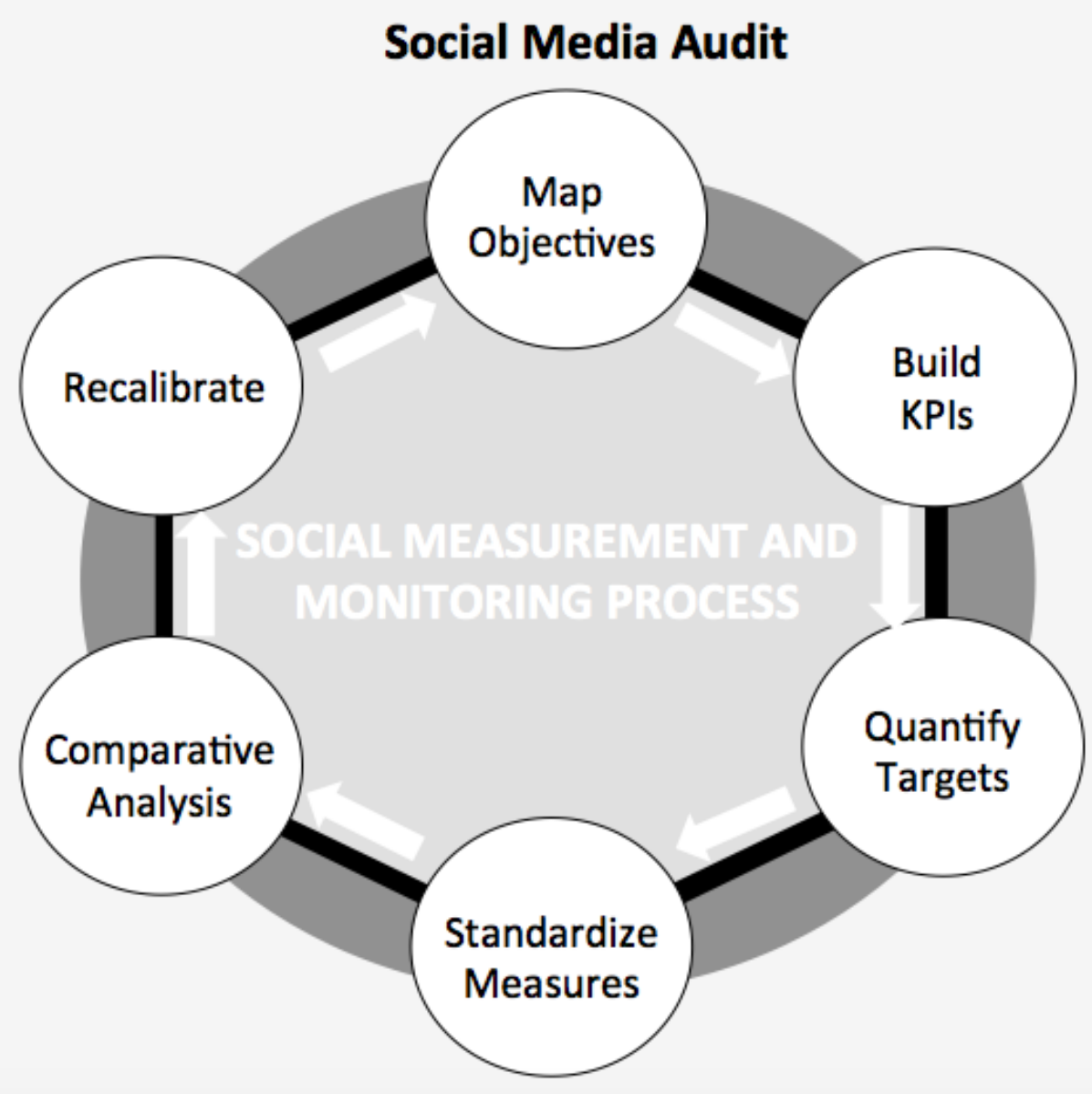

Fig 1: The Social Measurement and Monitoring Process (SMM Process) 
Table 1: Social Media Audit Template

\begin{tabular}{|c|c|c|c|c|c|c|}
\hline $\begin{array}{l}\text { Social } \\
\text { Media } \\
\text { Platform }\end{array}$ & \multicolumn{2}{|c|}{ Presence } & $\begin{array}{l}\text { Frequency } \\
\text { of Use }\end{array}$ & $\begin{array}{l}\text { Engagement } \\
\text { Level }\end{array}$ & $\begin{array}{l}\text { Number of } \\
\text { Followers }\end{array}$ & $\begin{array}{l}\% \\
\text { Change }\end{array}$ \\
\hline \multicolumn{7}{|l|}{ Facebook } \\
\hline \multicolumn{7}{|l|}{ Instagram } \\
\hline \multicolumn{7}{|l|}{ Twitter } \\
\hline \multicolumn{7}{|l|}{ Snapchat } \\
\hline \multicolumn{7}{|l|}{ YouTube } \\
\hline \multicolumn{7}{|l|}{ LinkedIn } \\
\hline \multicolumn{7}{|l|}{ Pinterest } \\
\hline \multicolumn{7}{|l|}{ Google + } \\
\hline \multicolumn{7}{|l|}{ Tumbler } \\
\hline \multicolumn{7}{|l|}{ Other } \\
\hline \multicolumn{7}{|l|}{ Parameter Key } \\
\hline \multicolumn{2}{|l|}{ Presence } & $\begin{array}{l}\text { Yes } \\
\text { No }\end{array}$ & & & & \\
\hline \multicolumn{2}{|c|}{ Frequency of Use } & $\begin{array}{l}\text { Not } \\
\text { Infre } \\
\text { Daily } \\
\text { Hou } \\
24 / 7\end{array}$ & $\begin{array}{l}\text { lonitored } \\
\text { quent: Monitor } \\
\text { Monitored at } \\
\text { y: Monitored } \\
\text { Monitored ro }\end{array}$ & $\begin{array}{l}\text { in a While } \\
\text { st once a day bu } \\
\text { tleast once an } \\
\text { d the clock (Live }\end{array}$ & $\begin{array}{l}\text { not hourly } \\
\text { lour but not ro } \\
\text { Monitoring) }\end{array}$ & und the clock \\
\hline \multicolumn{2}{|c|}{$\begin{array}{l}\text { Engagement (From } \\
\text { content/Marketers } \\
\text { perspective) }\end{array}$} & $\begin{array}{l}\text { No E } \\
\text { Low } \\
\text { Med } \\
\text { High }\end{array}$ & $\begin{array}{l}\text { gagement: Pr } \\
\text { Engagement: } \mathrm{N} \\
\text { um Engageme } \\
\text { Engagement : }\end{array}$ & $\begin{array}{l}\text { ence Only } \\
\text { nitoring Only } \\
\text { Monitoring and } \\
\text { ntent, Conversat }\end{array}$ & $\begin{array}{l}\text { Content Repostin } \\
\text { on and Custome }\end{array}$ & $\begin{array}{l}\text { ng } \\
\text { r Service }\end{array}$ \\
\hline \multicolumn{2}{|l|}{$\begin{array}{l}\text { Number of } \\
\text { Followers } \\
\end{array}$} & $\begin{array}{l}\text { Num } \\
\text { com }\end{array}$ & $\begin{array}{l}\text { eric Input (T } \\
\text { any/brand pa }\end{array}$ & $\begin{array}{c}\text { number of } \\
\text { /account) }\end{array}$ & urrent follower & s/fans of the \\
\hline \multicolumn{2}{|l|}{ \% Change } & $\begin{array}{l}\text { Reco } \\
\text { last } 1\end{array}$ & $\begin{array}{l}\text { ds the increa } \\
\text { lonth or last } y\end{array}$ & /decrease in nu & mber of followe & rs either from \\
\hline
\end{tabular}


Table 1: Social Media Audit Template

\section{Table 2: Social Media Objectives and Drivers}

\begin{tabular}{lll}
\hline \multicolumn{1}{c}{ Business Driver } & \multicolumn{1}{c}{ Strategic Objective } & \multicolumn{1}{c}{ Tactical Objective } \\
\hline Market and Consumer Insights & Engagement \& Influence, Reach, Revenue & Service feedback, Product feedback \\
\hline New Markets & Reach & Brand awareness \\
\hline Sales & Revenue & Engagement and website \\
\hline Customer Satisfaction, Loyalty & Engagement \& Influence & Customer service, promotions \\
\hline Brand equity & Engagement \& Influence & Develop engaging content \\
\hline
\end{tabular}

Table 2: Social Media Objectives and Drivers 


\section{Figure 2: Influence a brand can capitalize on}

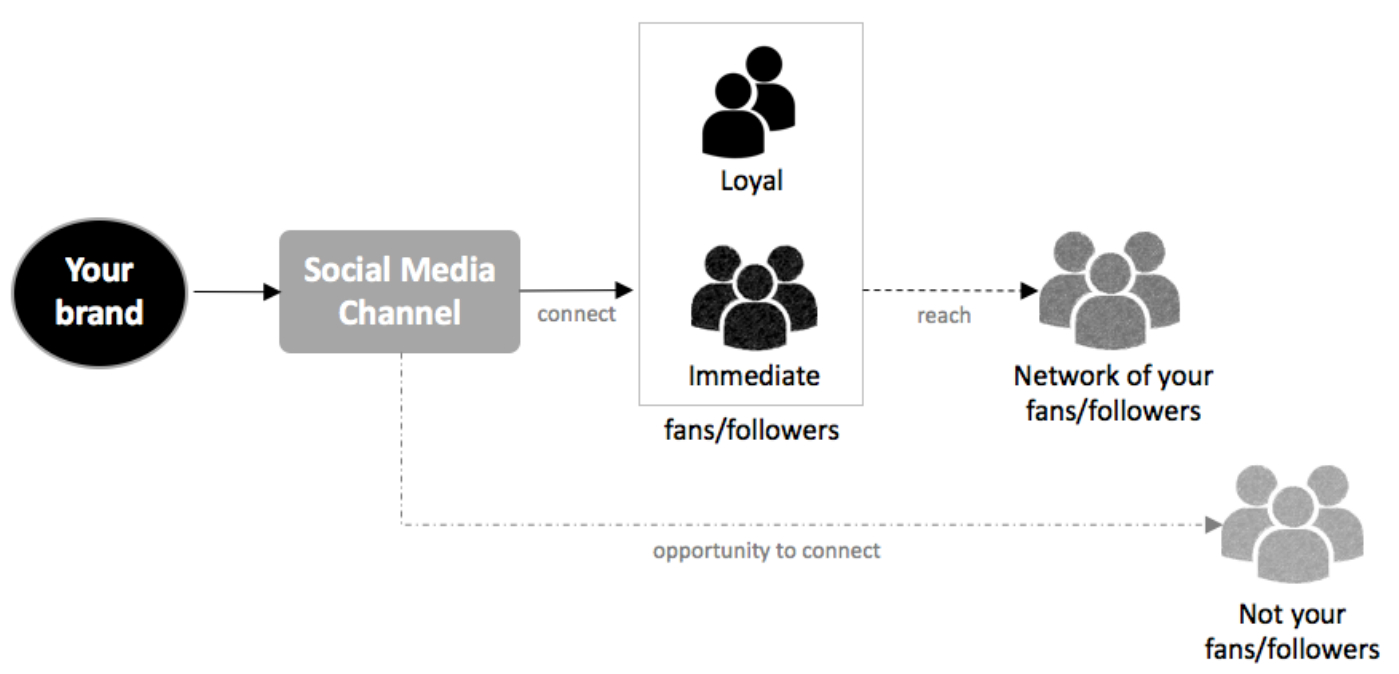

Figure 2: Influence a brand can capitalize on

Table 3: Organizing the Performance metric, purpose and KPIs

\begin{tabular}{|c|c|c|c|}
\hline $\begin{array}{l}\text { Performance } \\
\text { Metric }\end{array}$ & Reach & $\begin{array}{l}\text { Influence } \quad \& \\
\text { Engagement }\end{array}$ & Raise Revenues \\
\hline $\begin{array}{l}\text { Tactical } \\
\text { Objective }\end{array}$ & $\begin{array}{l}\text { Increase } \\
\text { awareness }\end{array}$ & $\begin{array}{l}\text { Generate leads and } \\
\text { nurture relations }\end{array}$ & Sales growth \\
\hline KPIs & $\begin{array}{l}\text { - Fan growth rate } \\
\text { - Content reach } \\
\text { - ... } \\
\text { - ... } \\
\text { - ... } \\
\text { - ... } \\
\text { - ... }\end{array}$ & $\begin{array}{l}\text { - Sentiment } \\
\text { indicator } \\
\text { - Share } \\
\text { conversations vs. } \\
\text { competitors } \\
\text { - Amplification rate } \\
\text { - Applause rate } \\
\text {-... } \\
\text { - ... }\end{array}$ & $\begin{array}{l}\text { - Social Media } \\
\text { Return } \\
\text { Investment } \\
\text { - Sales from social } \\
\text { media leads } \\
\text { - ... } \\
\text { - ... } \\
\text { - ... }\end{array}$ \\
\hline
\end{tabular}

'...' denotes more KPIs, custom KPIs relevant to the brand

Table 3: Organizing the Performance metric, purpose and KPIs 


\section{Table 4: Exercise template - Defining a KPI}

Using the following template, build a KPI to measure an objective

\begin{tabular}{|c|c|}
\hline KPI & $<$ Name of the KPI> \\
\hline $\begin{array}{l}\text { Performance } \\
\text { Metric }\end{array}$ & $<$ Business metric under consideration $>$ \\
\hline Tactical Objective & $<$ Purpose of this metric $>$ \\
\hline Definition & $<$ Define the KPI > \\
\hline Description & $\begin{array}{l}<\text { Describe the KPI, highlight correlation or dependency, if } \\
\text { any }>\end{array}$ \\
\hline Target & $\begin{array}{l}<\text { Outline tangible, measurable goal for KPI under } \\
\text { consideration> }\end{array}$ \\
\hline Calculation & $<$ Provide an equation on how this KPI will be computed $>$ \\
\hline Example & $\begin{array}{l}<\text { Provide an example to support the basis of the } \\
\text { calculation }>\end{array}$ \\
\hline Comparative & $\begin{array}{l}<\text { Evaluate all the possible benchmarking parameters for } \\
\text { the KPI> }\end{array}$ \\
\hline Visualization & $\begin{array}{l}<\text { Outline the graphic representation techniques for } \\
\text { reporting }>\end{array}$ \\
\hline
\end{tabular}

Table 4: Exercise template - Defining a KPI 


\section{Figure 3: Example - Developing Social KPIs from metrics to tactics}

\begin{tabular}{|c|c|c|c|c|}
\hline Metrics & Goals & KPI & Target & Tactics \\
\hline Reach & $\begin{array}{c}\text { Grow } \\
\text { fan/follower base }\end{array}$ & Fan growth rate & $\begin{array}{l}75 \% \text { in Quarter } 3 \\
75 \% \text { in organic reach } \\
20 \% \text { in viral reach } \\
5 \% \text { in paid reach }\end{array}$ & $\begin{array}{l}\text { - } 15 \text { content creation } \\
\text { - } 8 \text { full time equivalent } \\
\text { - } 4 \text { social channels } \\
\text { - } \ldots\end{array}$ \\
\hline
\end{tabular}

'...' denotes more tactic, custom tactics relevant to the brand

Figure 3: Example - Developing Social KPIs from metrics to tactics

\section{Table 5: Various computations to determine fan/follower growth}

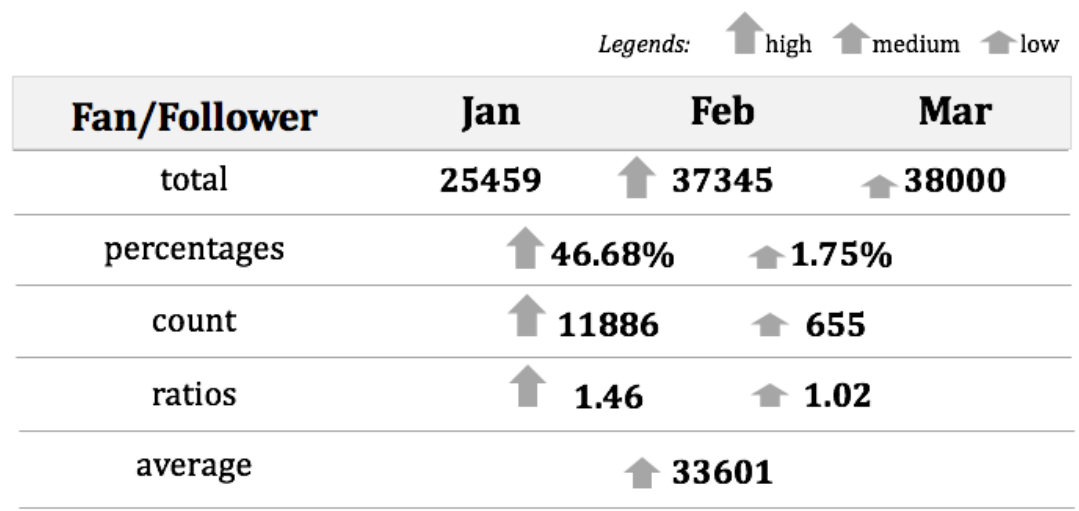

Table 5: Various computations to determine fan/follower growth 
Table 6: Comparative analysis of fan growth for January

United Kingdom

\begin{tabular}{ccc} 
Name & Fans & Fan Growth \\
\hline Company A & $\mathbf{2 5 4 5 9}$ & $+\mathbf{0 . 7 6 \%}$ \\
\hline Company B & $\mathbf{6 3 8 7 5}$ & $+\mathbf{1 . 5 2 \%}$ \\
\hline Company C & $\mathbf{1 1 2 4 5}$ & $-\mathbf{0 . 6 5 \%}$ \\
\hline
\end{tabular}

Table 6: Comparative analysis of fan growth for January 


\section{Table 7: Fan Growth Rate}

\section{Fan Growth Rate}

\begin{tabular}{|c|c|}
\hline Performance Metric & Reach \\
\hline Tactical Objective & Increase brand awareness \\
\hline Definition & $\begin{array}{l}\text { The ability to track your fans / followers growing over a } \\
\text { period of time. }\end{array}$ \\
\hline Description & $\begin{array}{l}\text { Fan growth rate allows brands to track fans/followers } \\
\text { growing over time. Fan growth rate is useful when appraising } \\
\text { how quickly the brand is growing. Such a KPI will help } \\
\text { estimate the influence potential the brand can capitalize by } \\
\text { reaching out to its fans/followers and possibly engaging with } \\
\text { them. Brands must not just rely on one KPI to determine the } \\
\text { success of a campaign, but instead all relevant and correlated } \\
\text { KPIs such as engagement KPIs or content consumption KPIs } \\
\text { must be used in conjunction with a specific KPI to build } \\
\text { relevant insights. }\end{array}$ \\
\hline Target & Based on Analysis (See Section 3.4) \\
\hline Calculation & $\begin{array}{l}\text { Total Fan Growth Rate } \%=[(\text { Present data }- \text { Past data }) / \text { Past } \\
\text { data })]^{* 100}\end{array}$ \\
\hline Example & $\begin{array}{l}\text { Say, } \\
\text { Followers in [Social Media Network] on July } 1^{\text {st }}=100000 \\
\text { Followers in [Social Media Network] on July } 30^{\text {th }}=165000 \\
\text { Followers in [Social Media Network] on September } 30^{\text {th }}= \\
175000 \\
\text { Fan Growth Rate } \% \\
=[(165000-100000) / 100000]^{*} 100=65 \% \text { over } 30 \text {-day period } \\
=[(175000-100000) / 100000]^{*} 100=75 \% \text { over a quarter } \\
\text { In this case, the brand observed only } 6.06 \% \text { increase in fan } / \\
\text { follower base between July and September }\end{array}$ \\
\hline Comparative & $\begin{array}{l}\text { The fan growth rate can be drilled down by region, country, } \\
\text { county/state, city across one or more social media channels. } \\
\text { Further, the relative share of fans / followers can be } \\
\text { determined by drilling into specific brand(s) and products or } \\
\text { services within the brand(s). Also, the fan growth rate can be } \\
\text { measured against competitor's brand. }\end{array}$ \\
\hline
\end{tabular}




\section{Table 8: Sentiment Indicator}

\section{Sentiment Indicator}

\begin{tabular}{|c|c|}
\hline Performance Metric & Influence \& Engagement \\
\hline Tactical Objective & Customer satisfaction \\
\hline Definition & $\begin{array}{l}\text { The ability to deduce how someone feels about a specific product, } \\
\text { service or brand. }\end{array}$ \\
\hline Description & $\begin{array}{l}\text { The sentiment indicator is based on set of positive or negative } \\
\text { information i.e. keywords, texts or group of words from one or more } \\
\text { social media channels. The classification of positive or negative } \\
\text { information is based on a pre-defined rules, usually created based on } \\
\text { natural language processing1, either offered by the social media } \\
\text { channels or custom prepared by brands. E.g. "Thank you so much } \\
\text { [brand name]". In this example, 'Thank you so much' is a close } \\
\text { proximity to an expression which is almost always positive, and this } \\
\text { will be classified as positive. }\end{array}$ \\
\hline Target & Based on Analysis (See Section 3.4) \\
\hline Calculation & $\begin{array}{l}\text { Sentiment Indicator } \%=[(\text { Positive }- \text { Negative }) / \text { (Positive }+ \\
\text { Negative })] * 100\end{array}$ \\
\hline Example & $\begin{array}{l}\text { Say, } \\
\text { Total conversations }=500 \\
\text { Positive conversations }=10 \\
\text { Negative conversations }=20 \\
\text { Neutral conversations }=470 \\
\text { Sentiment Indicator }=(10-20) / 500=(\text { Negative }) 2 \%=\text { Negative }\end{array}$ \\
\hline Comparative & $\begin{array}{l}\text { The sentiments can be drilled down by region, country, county/state, } \\
\text { city across one or more social media channels for a specific brand, } \\
\text { product or service to determine the who is talking about the brand } \\
\text { and where is it being talked about? }\end{array}$ \\
\hline Visualization & Heatmap, Sentiment Meter, Pie chart \\
\hline
\end{tabular}

Table 8: Sentiment Indicator 


\section{Table 9: Share of conversations vs. Competitors}

\begin{tabular}{|c|c|}
\hline \multicolumn{2}{|c|}{ Share of conversations vs. Competitors } \\
\hline Performance Metric & Influence \& Engagement \\
\hline Tactical Objective & Brand engagement \\
\hline Definition & $\begin{array}{l}\text { The ability to deduce the number of mentions in an online } \\
\text { conversation for the brand against that of the competitor's } \\
\text { brand within a given market and channel. }\end{array}$ \\
\hline Description & $\begin{array}{l}\text { The share of conversations tracks actual conversations, and } \\
\text { any mentions, about the brand(s). If the brand is not already } \\
\text { being spoken about, then you can identify the right } \\
\text { conversations to participate in. The share of conversations and } \\
\text { the sentiment indicator together will provide great insights } \\
\text { that enables the brand to react quickly to a negative scenario or } \\
\text { act to engage in a positive one. The closer you are to the } \\
\text { conversations, the better the position you are in to influence } \\
\text { the consumer or the influencer, and the higher is the value } \\
\text { gained from their conversations. }\end{array}$ \\
\hline Calculation & $\begin{array}{l}\text { Share of conversations vs. competitors } \%=\text { (Number of } \\
\text { mentions for [brand name A]/ Total number of mentions for } \\
[\text { brand name } B, C, D \ldots]) * 100\end{array}$ \\
\hline Target & Based on Analysis (See Section 3.4) \\
\hline Example & $\begin{array}{l}\text { Say, } \\
\text { Mentions for Brand } A=10 \\
\text { Mentions for Brand } B=20 \\
\text { Mentions for Brand } C=40 \\
\text { Mentions for Brand } D=30 \\
\text { Total Mentions }=100 \\
\text { Share of conversations vs. Competitors }=10 / 100=10 \%\end{array}$ \\
\hline Comparative & $\begin{array}{l}\text { The sentiments can be drilled down by region, country, } \\
\text { county/state, city across one or more social media channels for } \\
\text { a specific brand, product or service }\end{array}$ \\
\hline
\end{tabular}




\section{Table 10: Amplification Rate}

\begin{tabular}{|c|c|}
\hline \multicolumn{2}{|c|}{ Amplification Rate } \\
\hline Performance Metric & Influence \& Engagement \\
\hline Tactical Objective & Increase brand reach \\
\hline Definition & $\begin{array}{l}\text { The frequency at which the social media audience react to your } \\
\text { content and/or message and share it. }\end{array}$ \\
\hline Description & $\begin{array}{l}\text { Every time a content or message is reshared, retweeted, repined, } \\
\text { your message is amplified. In other words, amplification rate is the } \\
\text { measure of shares per post. } \\
\text { Amplification rate is positive when }>1 \text {, negative when }<1 \text {, neutral } \\
\text { when }=1 \text {. }\end{array}$ \\
\hline Calculation & $\begin{array}{l}\text { Amplification Rate }=\text { No. of Shares } / \text { (No. of Posts } * \text { No. of } \\
\text { fans/followers) }\end{array}$ \\
\hline Target & Based on Analysis (See Section 3.4) \\
\hline Example & $\begin{array}{l}\text { Say, for a given post, } \\
\text { Shares in Facebook }=50 \\
\text { Retweets in Twitter }=100 \\
\text { Total Shares = } 150 \\
\text { Assuming } 50 \text { fans, Amplification Rate Avg. }=150 /(1 * 50)=3 \\
\text { Assuming } 1500 \text { fans, Amplification Rate Avg. }=150 /(1 * 1500)=0.1\end{array}$ \\
\hline Comparative & $\begin{array}{l}\text { The sentiments can be drilled down by region, country, county/state, } \\
\text { city across one or more social media channels for a specific brand, } \\
\text { product or service. Further, the amplification rate can have relative } \\
\text { measures which allows to accurately compare between several } \\
\text { accounts that have different number of followers and when you wish } \\
\text { to compare against competitors. You may also calculate the overall } \\
\text { amplification for your campaign by considering an average of all the }\end{array}$ \\
\hline
\end{tabular}


messages posted during the campaign.

Visualization $\quad$ Histogram is one of the best visual representation to visually project the amplification rate over a period of time.

Table 10: Amplification Rate

\section{Table 11: Applause Rate Average}

\begin{tabular}{|c|c|}
\hline Performance Metric & Influence \& Engagement \\
\hline Tactical Objective & Increase brand reach \\
\hline Definition & $\begin{array}{l}\text { The frequency at which the social media audience react to your } \\
\text { content and/or message and like it. }\end{array}$ \\
\hline Description & $\begin{array}{l}\text { Every time a content or message is liked, loved, pinned, given a } \\
\text { thumbs up or }+1 \text {, then your message has been applauded. In other } \\
\text { words, it implies how many likes/favorites on average your post has } \\
\text { received. } \\
\text { Applause rate is positive when }>1 \text {, negative when }<1 \text {, neutral when = } \\
\text { 1. }\end{array}$ \\
\hline Calculation & Applause Rate $=$ No. of Likes $/$ (No. of Posts * No. of fans/followers) \\
\hline Target & Based on Analysis (See Section 3.4) \\
\hline Example & $\begin{array}{l}\text { Say, for a given post, } \\
\text { Likes in Facebook }=500 \\
\text { Heart in Twitter }=500 \\
\text { Total Likes }=1000 \\
\text { Assuming } 500 \text { fans, Applause Rate Avg. }=1000 /(1 * 500)=2 \\
\text { Assuming } 5000 \text { fans, Applause Rate Avg. }=1000 /(1 * 5000)=0.2\end{array}$ \\
\hline Comparative & $\begin{array}{l}\text { The sentiments can be drilled down by region, country, county/state, } \\
\text { city across one or more social media channels for a specific brand, } \\
\text { product or service. Further, the amplification rate can have relative } \\
\text { measures which allows to accurately compare between several } \\
\text { accounts that have different number of followers and when you wish } \\
\text { to compare against competitors. You may also calculate the overall } \\
\text { amplification for your campaign by considering an average of all the }\end{array}$ \\
\hline
\end{tabular}


messages posted during the campaign.

Visualization Histogram bar is one of the best visual representation to visually project the applause rate over a period of time.

\section{Table 12: Social Media Return on Investments (ROI)}

\begin{tabular}{|c|c|}
\hline \multicolumn{2}{|c|}{ Social Media Return on Investments (ROI) } \\
\hline Performance Metric & Raising revenues \\
\hline Tactical Objective & Return on Investment \\
\hline Definition & The ability to measure the returns on your overall social media goals \\
\hline Description & $\begin{array}{l}\text { While outlining the social media ROI, it is important to introspect, } \\
\text { how you define the social media ROI. It is very powerful KPI with an } \\
\text { objective to measuring sales. It is important that you consider your } \\
\text { CAPEX and OPEX spend, as well as any promotional costs, across } \\
\text { channels. These become your total investment which needs to be } \\
\text { measured against the number of conversions via social media that } \\
\text { resulted in sales. It is the value you derive from one or more social } \\
\text { media channels based on the campaign targets. A positive ROI is } \\
\text { considered better and more efficient than a negative ROI. }\end{array}$ \\
\hline Calculation & $\begin{array}{l}\text { ROI }=[(\text { Revenue generated by Social Media - Total Social Media } \\
\text { Expenses }) /(\text { Total Social Media Expenses })]^{*} 100\end{array}$ \\
\hline Target & Based on Analysis (See Section 3.4) \\
\hline Example & $\begin{array}{l}\text { Say, } \\
\text { Revenues from multiple social channels }=\text { US\$ 500,000 } \\
\text { Total CAPEX and OPEX invested in social media }=\text { US\$ } 200,000 \\
\text { Then, ROI }=[(500000-200000) / 200000] * 100=150 \%\end{array}$ \\
\hline Comparative & $\begin{array}{l}\text { Use the KPI to measure ROI across one or more campaigns, across } \\
\text { one or more geographies, demographics, and social media channels. } \\
\text { Further, use the social ROI against the overall sales generated to } \\
\text { determine the percentage of revenue share from social media. }\end{array}$ \\
\hline Visualization & $\begin{array}{l}100 \% \text { stacked bar is one of best visual representation to visually } \\
\text { project the social media ROI. You may also look into Pie charts. }\end{array}$ \\
\hline
\end{tabular}


Table 12: Social Media Return on Investments (ROI)

\section{Table 13: Sales from Social Media Leads}

\begin{tabular}{|c|c|}
\hline \multicolumn{2}{|c|}{ Sales from Social Media Leads } \\
\hline Performance Metric & Influence \& Engagement \\
\hline Tactical Objective & Sales \\
\hline Definition & $\begin{array}{l}\text { The ability to measure the sales on average order value or } \\
\text { customer lifetime value on qualified converted leads }\end{array}$ \\
\hline Description & $\begin{array}{l}\text { Sales measurement enable to evaluate the sales derived from a } \\
\text { lead across one or more channels and can be calculated either } \\
\text { on average order value as well as forecasted at customer } \\
\text { lifetime value. A tangible sales target will enable brands to } \\
\text { measure the business guidance around a specific campaign or } \\
\text { channel or the overall social media ecosystem }\end{array}$ \\
\hline Calculation & $\begin{array}{l}\text { Sales from Social Media Lead (Average Order Value })=[(\text { No. of } \\
\text { qualified social media leads identified }) *(\% \text { lead-to-customer } \\
\text { conversion rate }) * \text { average order value })]\end{array}$ \\
\hline & $\begin{array}{l}\text { Sales from New Social Media Lead (Customer Lifetime Value) } \\
=[(\text { No. of qualified online social leads identified }) *(\% \text { lead-to- } \\
\text { customer conversion rate }) * \text { customer lifetime value })]\end{array}$ \\
\hline Target & Based on Analysis (See Section 3.4) \\
\hline Example & $\begin{array}{l}\text { Say, } \\
\text { No. of qualified social media leads }=1000 \\
\% \text { lead-to-customer conversion rate }=10 \% \\
\text { Average order value (AOV) = US \$120 } \\
\text { Customer Lifetime Value (CLV) = US \$ } 2000 \\
\text { Sales from Social Lead (AOV) }=[1000 * 10 \% * 120]=\text { US\$ } \\
12000 \\
\text { Sales from New Social Lead (CLV) }=[1000 * 10 \% * 2000]= \\
\text { US\$ } 200000\end{array}$ \\
\hline Comparative & $\begin{array}{l}\text { Use the KPI to measure the sales lead across geographies, } \\
\text { demographics and social channels. }\end{array}$ \\
\hline
\end{tabular}




\section{Figure 4: Tweet Sentiment Visualization for Key Word "PokemonGo"}

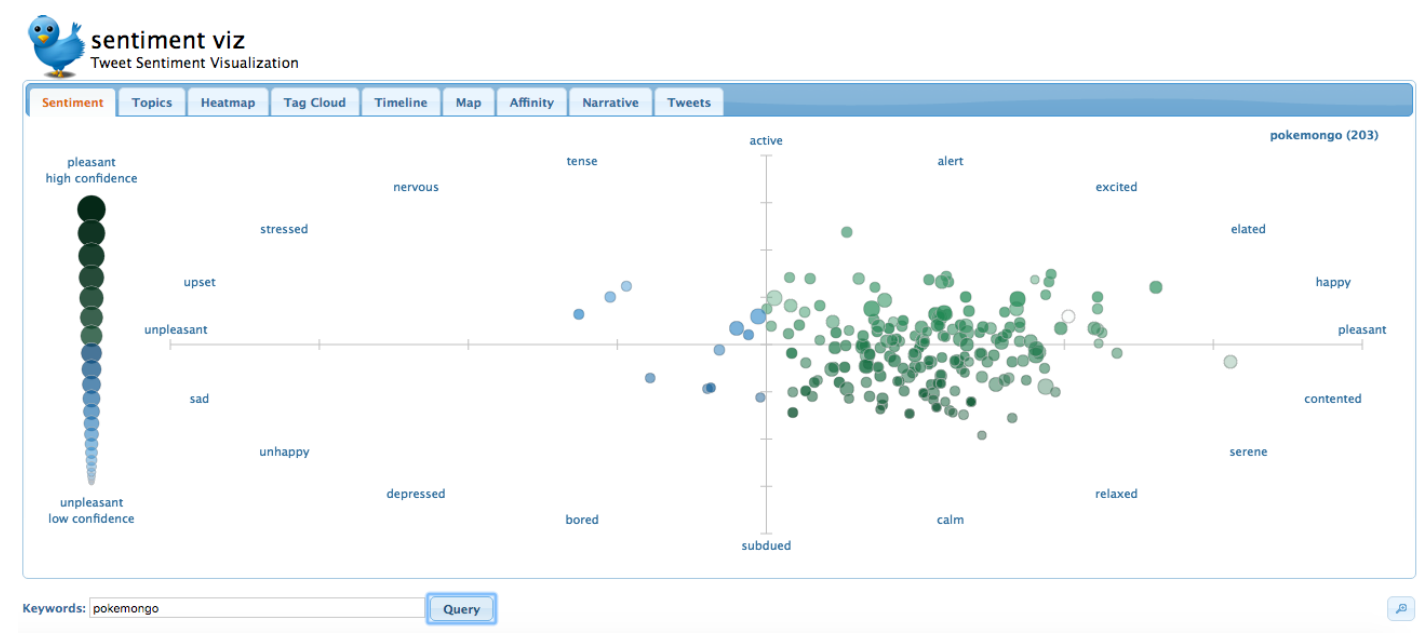

Figure 3: Tweet Sentiment Visualization for Key Word "PokemonGo" 
Figure 5: Tweet Sentiment Visualization for Key Word "PokemonGo" showing a high confidence/pleasant and alert/active tweet.

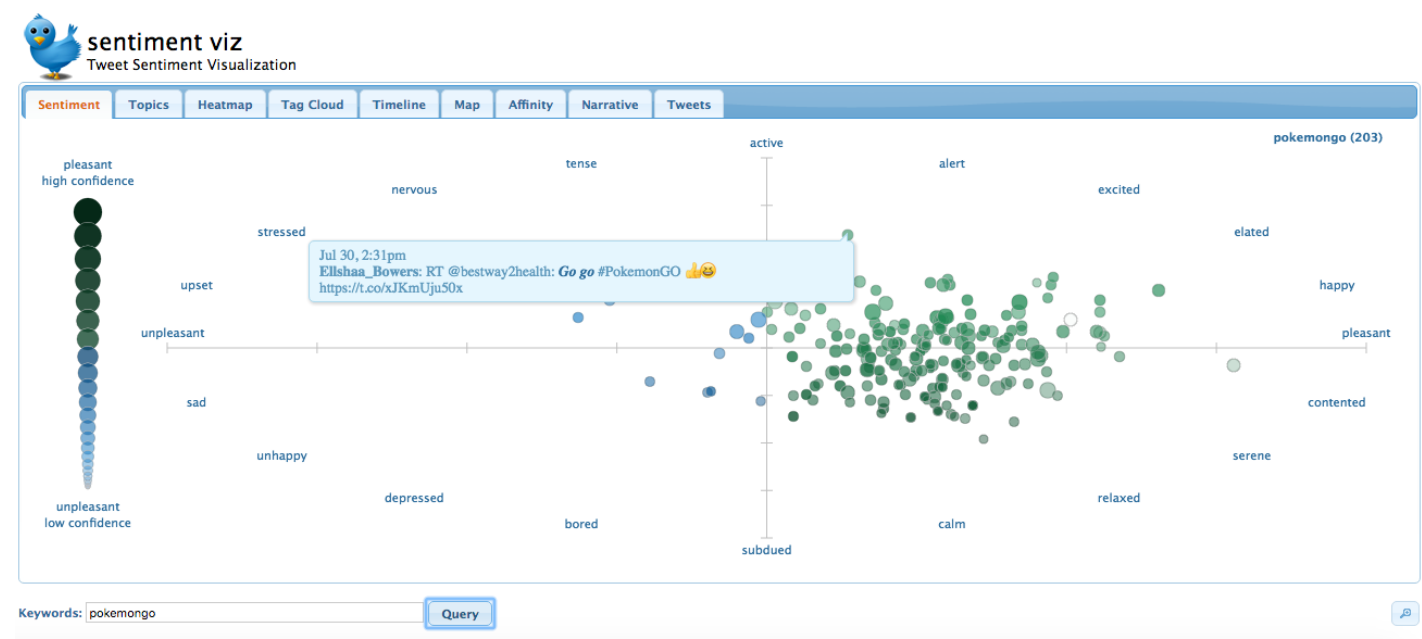

Figure 4: Tweet Sentiment Visualization for Key Word "PokemonGo" showing a high confidence/pleasant and alert/active tweet

Figure 6: Bar chart - Number of Fans/Followers for different brands against competitor for a given period

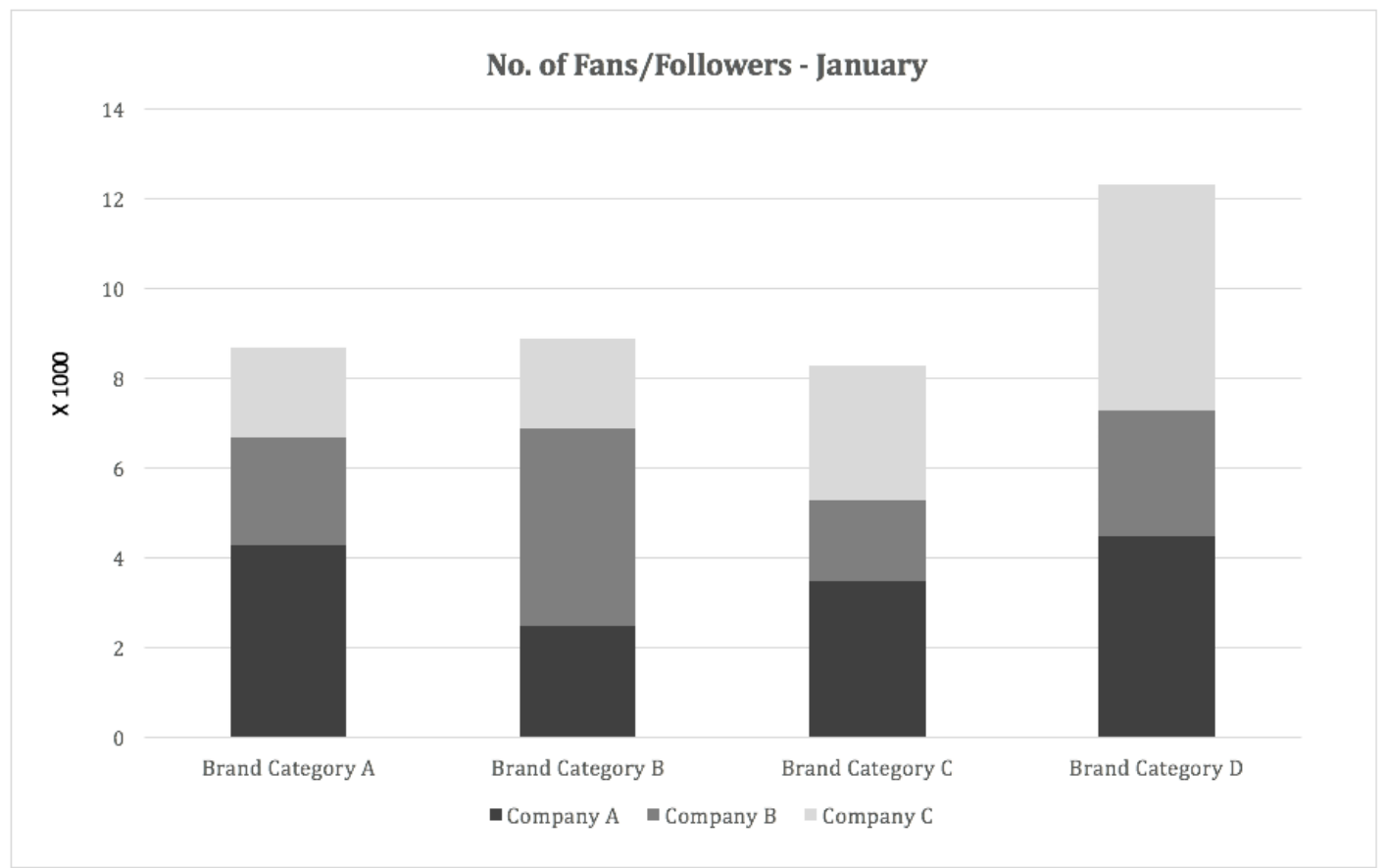


Figure 6: Bar chart - No. of Fans/Followers for brands against competitor in a given period 